\title{
DESIGNING, CONSTRUCTION, ASSESSMENT, AND EFFICIENCY OF LOCAL EXHAUST VENTILATION IN CONTROLLING CRYSTALLINE SILICA DUST AND PARTICLES, AND FORMALDEHYDE IN A FOUNDRY INDUSTRY PLANT
}

\author{
Mortezavi Mehrizi MORTEZA, Kakooi HOSSEIN², Matin AMIRHOSSEIN ${ }^{3}$, Hasheminegad \\ NASER $^{4}$, Halvani GHOLAMHOSSEIN ${ }^{1}$, and Fallah HOSSEIN ${ }^{1}$
}

School of Health, Shahid Sadoughi University of Medical Sciences, Yazd', School of Health, Tehran University of Medical Sciences,Tehran ${ }^{2}$, School of Health, Shahid Beheshti University of Medical Sciences, Tehran ${ }^{3}$, School of Health, Kerman University of Medical Sciences, Kerman 4 , Iran

Received in January 2012

CrossChecked in January 2013

Accepted in January 2013

\begin{abstract}
The purpose of the present study was to design and assess the efficiency of a local exhaust ventilation system used in a foundry operation to control inhalable dust and particles, microcrystal particles, and noxious gases and vapours affecting workers during the foundry process. It was designed based on recommendations from the American Conference of Governmental Industrial Hygiene. After designing a local exhaust ventilation system (LEV), we prepared and submitted the implementation plan to the manufacturer. High concentrations of crystalline silica dust and formaldehyde, which are common toxic air pollutants in foundries, were ultimately measured as an indicator for studying the efficiency of this system in controlling inhalable dust and particles as well as other air pollutants. The level of occupational exposure to silica and formaldehyde as major air pollutants was assessed in two modes: first, when the LEV was on, and second, when it was off. Air samples from the exposure area were obtained using a personal sampling pump and analysed using the No. 7601 method for crystal silica and the No. 2541 method for formaldehyde of the National Institute for Occupational Safety and Health (NIOSH). Silica and formaldehyde concentrations were determined by visible absorption spectrophotometry and gas chromatography. The results showed that local exhaust ventilation was successful in preserving the crystal silica particles in the work environment at a level below the NIOSH maximum allowed concentration $\left(0.05 \mathrm{mg} \mathrm{m}^{-3}\right)$. In contrast, formaldehyde exceeded the NIOSH limit (1 ppm or $\left.1.228 \mathrm{mg} \mathrm{m}^{-3}\right)$.
\end{abstract}

KEY WORDS: inhalable dust and particles, local ventilation, occupational exposure

Foundry workers are continuously exposed to compounds such as crystal silica, polycyclic aromatic hydrocarbons $\left(\mathrm{PAH}_{\mathrm{S}}\right)$, formaldehyde, and toxic metals. Crystal silica makes up for a significant portion of the sand used in the moulding, mixing and vibration that take place during a founding operation. According to a report from the International Agency of Research on Cancer (IARC), there is convincing evidence that the classification of crystal silica in the form of quartz should be upgraded from probably carcinogenic for humans to carcinogenic for humans. The findings of some studies also indicate that occupational exposure to silica during the casting operation of foundry may lead to respiratory tract diseases and cause damage to 
one's pulmonary function (1). At the turn of the $21^{\text {st }}$ century, the Metropolitan Life Insurance Company, New York, USA reported that foundry workers, stone miners, and other miners had taken more days off work than workers from any other profession (2).

The lung is the first target tissue for crystal silica. Besides the lung, formaldehyde and benzene also affect the larynx $(2,3)$. The disorders caused by occupational exposure to crystal silica have been identified by specialists many years ago $(1,2)$.

Silica dust is created during the mixing operation, melting, shakeout, dressing, as well as during the stone preparation process and recycling. The air dust concentration varies depending on the transportation process, efficiency of dust control, chemical combination and physical form of the stone, sieving method, and amount of moisture contained (4). The use of local ventilation systems serves as an engineering control in industries with an air-polluted environment. The Local Exhaust Ventilation (LEV) removes the polluted air and transmits the pollutants away from the work environment. The polluted air can also be refined before exiting into the outside environment.

Therefore, an exact and accurate design for ventilation hoods, refiners and purifiers, as well as a proper installation of air canals in the work environment, is of the utmost significance (6). Most metal foundry processes use raw materials such as foundry sand mixture, which contains silica sand, coal particles, and organic connectors such as dextrin, and carbon oil. Foundry sand can be reused. If reused, it may contain previously founded macroscopic or microscopic metal particles. Sometimes, resin components are used in the founding process. The processes encompassed by industrial foundry include moulding, model construction, core-making, melting, founding, shakeout, dressing, and cleaning. These processes are carried out in three separate halls. However, in the observed factory, the core-making and melting processes are separated from other processes.

The equipment used in these processes includes: pneumatic conveyors, a feeding conveyor, bin, sand mixer, multi-sided screen, cooling tower, elevator, cooling line, cooling drum, apron conveyor, vibrating conveyor, and magnet. Some of this machinery can be a source of pollution, but not necessarily one to which workers are exposed. However, it is better to undertake measures that will ensure separation. The instruments and equipment which are sources of pollution for the workers must be equipped with a local exhaust ventilation system in order to control the pollutants. Since the threshold limit values (TLV) of the abovementioned formaldehyde and crystalline silica in this industry are less than $100 \mathrm{ppm}$, dilution ventilation cannot be used with safety. For instance, the American Conference of Governmental Industrial Hygiene (ACGIH) recommends the use of dilution ventilation for low toxicity pollutants with TLVs of more than $100 \mathrm{ppm}$ (7).

The purpose of the present study was to design and assess the efficiency of a local ventilation system used in a foundry operation for the purpose of controlling inhalable dusts, crystalline silica dust, and gases and vapour that affect workers during the foundry process.

\section{METHODS}

\section{The study area}

Figure 1 shows the location and arrangement of foundry equipment in the hall both horizontally and vertically.

To design the local exhaust ventilation, intended only for certain sources of pollution, several ventilation standards (VS) were applied. For the pollutants for which there were no standard hoods, new hoods were designed based on the pollutant type, the method of pollutant production, the form of the pollutant source, and the location of the operator. This individual local exhaust ventilation was designed and fabricated according to the ACGIH.

The system was designed based on Method $\mathrm{C}$ of the ACGIH. In this method, the static pressure of each peripheral branch is balanced by its related main canal (7). The calculation sheet provided in this method provides a convenient format to organize the design process. In the design of a complex local exhaust system, it is important to use a consistent method of identifying the various hoods and duct sections. Each hood is assigned a number and each duct junction or transition is assigned a letter. A hood-to-junction or junction-to-junction duct run represented by a twocharacter combination (e.g., 1-A, H-I) was used to label the designed duct section. The ventilation standards used in the designing and implementation of this system included: VS-85-10 for the pneumatic conveyor; VS-50-10 for the bin, the weighting system and the sieve feeder; VS-99-01 for the multi-sided screen; and VS-50-21 for the cooling line and vibrating 



Figure 1 The location and arrangement of foundry equipment in the hall both horizontally and vertically.

conveyor. For other pollutants, the hoods were designed based on the pollutant type, pollutant production method, pollutant source form, and location of the operator. Among the factors considered in designing the ventilation systems were pressure correction indices and flow rate.

Variations in longitude and temperature lead to changes in density, which in turn causes changes in volume and types of pressure. Changes in longitude induce changes in pressure caused by the weight of the upper atmospheric layers. Consequently, descending volume changes arise due to a decrease in longitude, and ascending volume changes due to an increase in longitude. Changes in temperature also cause changes in volume, i.e. an increase in temperature causes an increase in volume, while a decrease in temperature causes a decrease in volume. The air volume and pressure parameters are corrected by indices such as the correction index of flow rate $\left(K_{Q}\right)$ and pressure correction index $\left(K_{P}\right)$, respectively.

The canals, entrances, elbows, and hoods were made of black iron of the appropriate thickness. Factors determining the thickness of the channel are the material, the static pressure in each section of a channel and the channel diameter in each section of the ventilation system. The ventilator was designed on the basis of calculations and fabricated according to pollutant type. Figure 2 shows sources of air pollution.

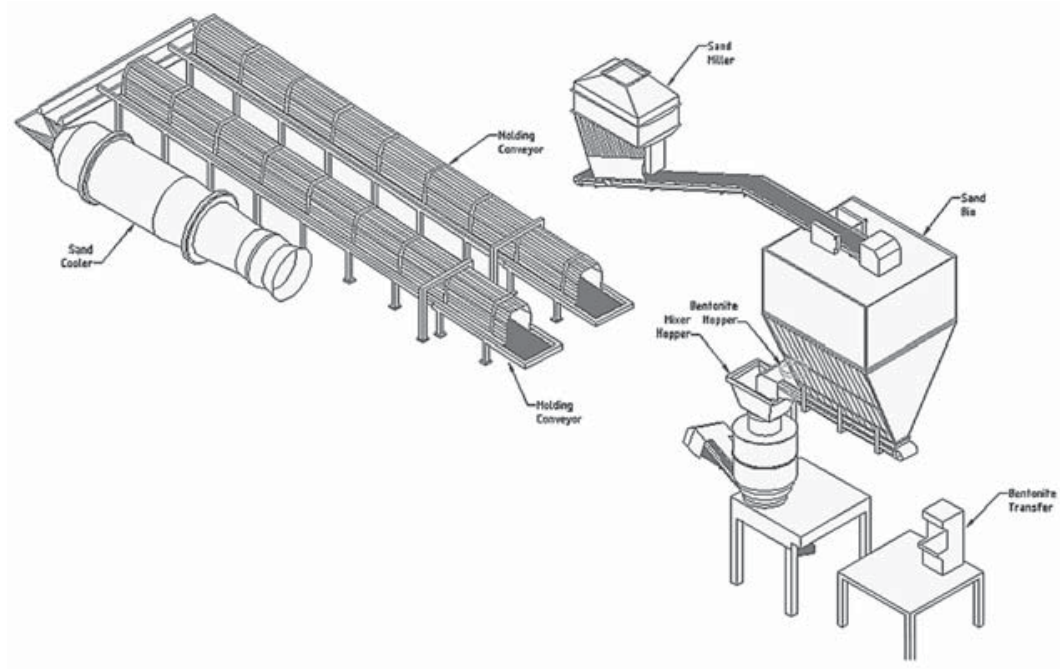

Figure 2 Arrangement and localization of air pollution sources 


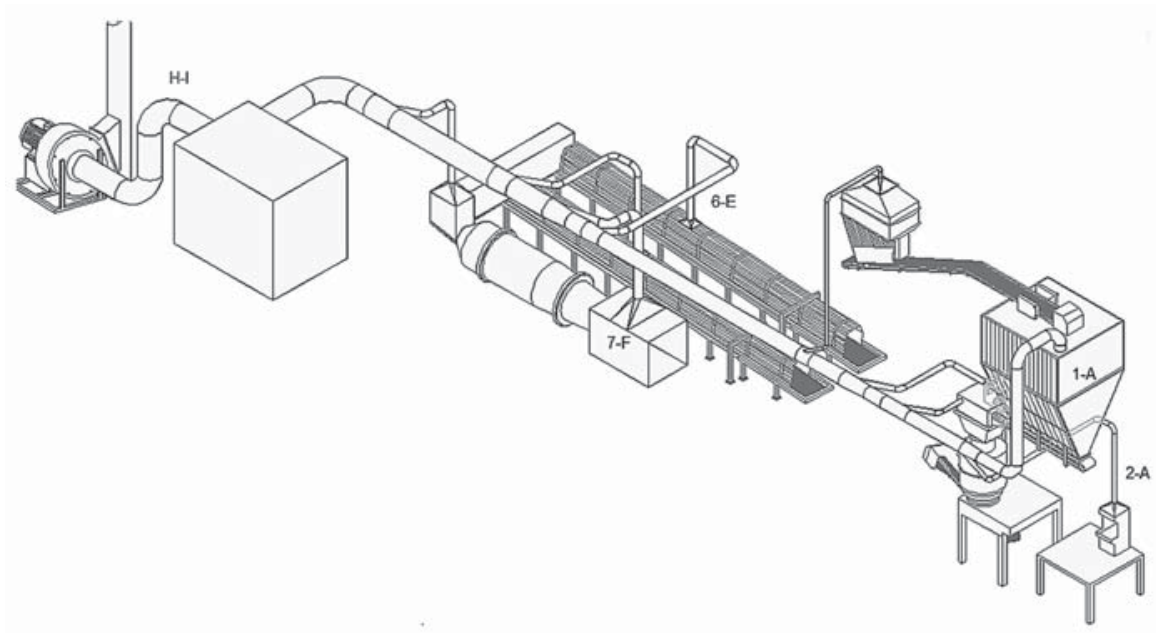

Figure 3 The local exhaust ventilation with ventilation standards for different sources of pollution

After fabrication and installation, the implementation and efficiency of all components were assessed from the viewpoint of fluid mechanics. The parameters studied included the measurement of flow rate in the face of the hood, air velocity in the face of hood, minimum design duct velocity, total pressure, velocity pressure, and static pressure. Then, these parameters were compared to the values proposed in the design. A pitot tube made by the Air Flow Company (UK) was used to measure the minimum design duct velocity, total pressure, velocity pressure, and static pressure, while a van anemometer manufactured by the same company was used to measure speed at the face of the hood. Both instruments were calibrated before use.

\section{INDIVIDUAL AIR SAMPLING AND ANALYSIS METHODS}

The silica and formaldehyde dusts and vapours were collected in two modes, "ventilation system on" and "ventilation system off", and their amounts were calculated and analyzed. A total of 40 personal samples of silica particles and 39 personal samples of formaldehyde were collected from the breathing zone comprising a population of 188 workers and analysed for exposure to crystalline silica and formaldehyde vapours. The studied population included all the personnel who were directly in contact with the contaminants. The group sampling technique was used in determining the number of samples. The studied population was divided into different occupational groups. According to the number of persons in each occupational group and the standard deviation of exposure to silica and formaldehyde, the number of samples was determined according to the following equation:

$$
n h_{i}=\frac{\left(N h_{i} / N \times S h_{i}\right)}{\sum_{i=1}^{n}\left(N h_{i} / N \times S h_{i}\right)} \times n
$$

Method No.7601 of the National Institute of Occupational Safety and Health (NIOSH) was used for collection and analysis of silica particles, and method No.2541 of the NIOSH for formaldehyde.

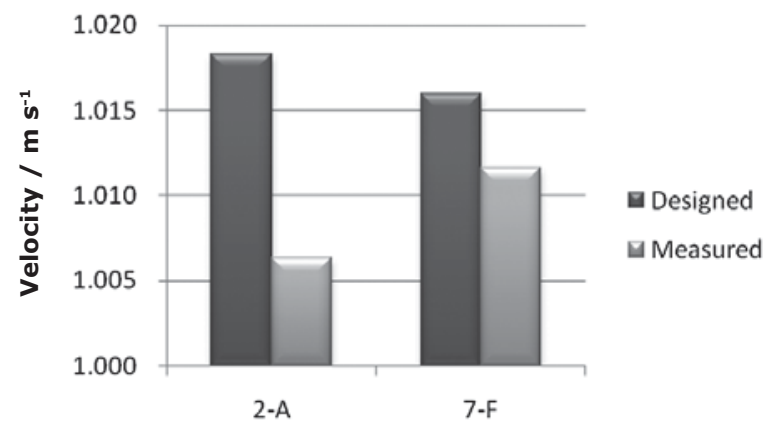

Figure 4 A comparison of the design values of face velocity of hoods with the measured values

All the silica samples were collected on a PVC membrane filer with a diameter of $37 \mathrm{~mm}$ and a pore size of $5 \mu \mathrm{m}$ using an HD cyclone with an output flow rate of $2.2 \mathrm{~L} \mathrm{~min}^{-1}$ and a total volume of $400 \mathrm{~L}$. During the sample collection procedure, precautions were taken not to use samples with a weight larger than 2 $\mathrm{mg}$. All formaldehyde samples were collected using solid sorbent tubes through surface absorption. The 
sorbent tubes contained 120/60 mg XAD-2 coated with Piperidine.

All the sampling processes were conducted using Method No.7601 and No.2541 of the NIOSH for crystal silica and formaldehyde, respectively (8). The pumps used for sampling were an individual pump and an SKC micro pump, model 224-44EX, for silica particles and formaldehyde vapour with a flow rate of $1.5 \mathrm{~L} \mathrm{~min}^{-1}$, for silica particles (8). A flow rate of 2.2 $\mathrm{L} \mathrm{min}^{-1}$ was used for sampling formaldehyde (9).

The pumps were calibrated by a rotameter. Because of the change in air pressure from $1013 \mathrm{hPa}$ to work environment pressure and the temperature change from $25{ }^{\circ} \mathrm{C}$ to that of the work environment, there were changes in the sampled air volume due to changes in air density. These changes were compensated for during the sampling process. The breakthrough for formaldehyde samples with an output of $1.5 \mathrm{~L} \mathrm{~min}^{-1}$ occurs within four hours. The samples for which the breakthrough was more than $10 \%$ were excluded from the study. The membrane filters containing respirable dust of no more than $2 \mathrm{mg}$ were put in a Petri dish, prepared, and quantified using a visible absorption spectrophotometer.

To determine the concentration of formaldehyde, the air samples were prepared, analysed and quantified using a gas chromatograph. All the chromatograms were done using a Shimadzu GC set, model 175A and a new flame detector. The obtained chromatograms were recorded via GC Real Time Analysis, while a standard curve was drawn to determine sample quantities.

In order to determine the velocity of air in each canal, velocity pressure was measured at several points in the duct. Then, the average of the measured values was determined, followed by the determination of average velocity by the equation: $v=4005 \sqrt{v p}$. Then, values of average velocity were compared with the designed velocity. One sample $t$-test was used.

\section{RESULTS}

2-A and 7-F are the second and seventh hood connected to the ventilation system at the first and sixth intersection, respectively.

This parameter was also measured in the ducts where the measurement of minimum design duct velocity was possible. Later it was compared to the measured values.

Ducts 1-A, 2-A and 6-E are the first, second and sixth ducts connected to the ventilation system at the first and fifth intersection, respectively, while $\mathrm{H}-\mathrm{I}$ is the end-duct of the ventilation system.

Figure 5 shows that the installed system functions as it was designed. In fact, the designed parameters are fully installed and stabilized according to parameters of ventilation system stability and the design. The findings show that $94 \%$ to $97 \%$ of the designed flow rate in this project is accessible due to the fact that the fan was designed on the basis of design parameters.

Table 3 shows the concentration of the mentioned pollutants before and after application of the new local evacuation system. The mean concentration value of crystal silica and formaldehyde before the application

Table 1 The comparison of measured values and designed values of face velocity of two hoods

\begin{tabular}{|c|c|c|c|c|c|}
\hline $\boldsymbol{P}_{\text {value }}{ }^{*}$ & $\begin{array}{c}\text { Standard } \\
\text { deviation } / \mathrm{m} \mathrm{s}^{-1}\end{array}$ & $\begin{array}{l}\text { The mean difference between } \\
\text { measured and designed values / } \mathrm{m} \mathrm{s}^{-1}\end{array}$ & $\begin{array}{c}\text { Designed } \\
\text { values / } \mathrm{m} \mathrm{s}^{-1}\end{array}$ & $\begin{array}{c}\text { Average measured } \\
\text { of values } / \mathrm{m} \mathrm{s}^{-1}\end{array}$ & $\begin{array}{l}\text { Profile } \\
\text { Hood }\end{array}$ \\
\hline 0.151 & 1.604 & 0.002 & 1.016 & 1.018 & $2-A$ \\
\hline$<0.001$ & 2.58 & 0.009 & 1.016 & 1.006 & $7-F$ \\
\hline
\end{tabular}

*one sample t-test

Table 2 Comparison of measured values and designed values of minimum design duct velocity

\begin{tabular}{lccccc}
\hline $\boldsymbol{P}_{\text {value }}$ & $\begin{array}{c}\text { Standard } \\
\text { deviation } / \mathbf{~ m ~ s}^{\mathbf{1}}\end{array}$ & $\begin{array}{c}\text { The mean difference between } \\
\text { measured and designd value } / \mathbf{~ m ~ s}^{\mathbf{1}}\end{array}$ & $\begin{array}{c}\text { Designed } \\
\text { values } / \mathbf{~ m ~ s}^{\mathbf{1}}\end{array}$ & $\begin{array}{c}\text { Average measured } \\
\text { values } / \mathbf{~ m ~ s}^{\mathbf{1}}\end{array}$ & $\begin{array}{c}\text { Profile } \\
\text { canal }\end{array}$ \\
\hline$<0.001$ & 91.177 & 0.384 & 25.4 & 25.02 & $1-\mathrm{A}$ \\
\hline$<0.001$ & 51.794 & 0.29 & 24.64 & 24.35 & $2-\mathrm{A}$ \\
0.133 & 91.3 & 0.163 & 30.76 & 30.59 & $6-\mathrm{E}$ \\
0.308 & 551 & 0.645 & 24.44 & 23.39 & $\mathrm{H}-\mathrm{L}$ \\
\hline
\end{tabular}




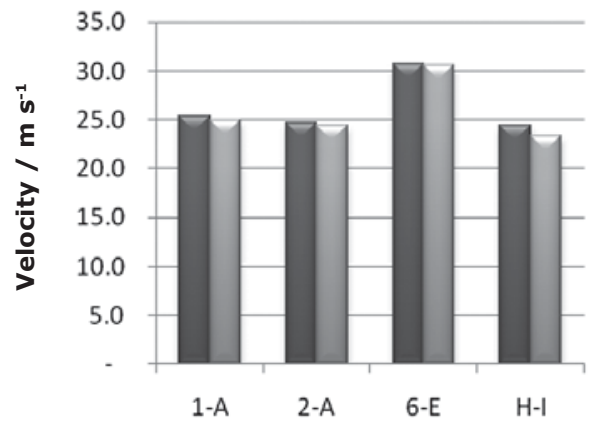

Figure $5 \mathrm{~A}$ comparison between the minimum design duct velocity and the measured values

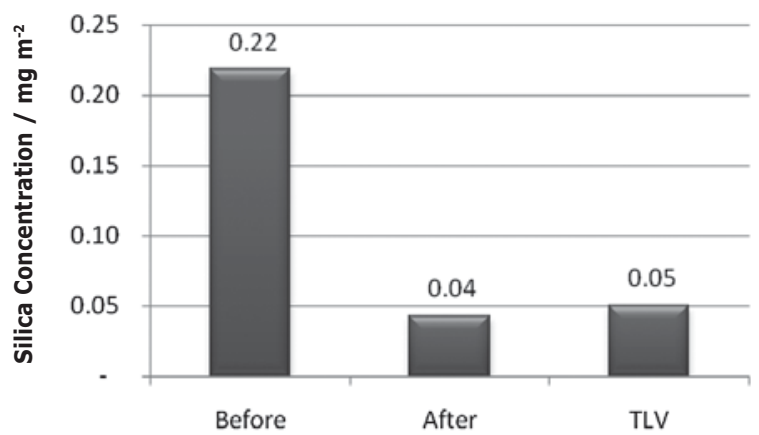

Figure 6 A comparison of mean concentration of crystal silica measured using individual samplers before and after implementation of the local exhaust ventilation. The threshold limit value (TLV) established by the NIOSH is also shown.

of the new system was $0.218 \mathrm{mg} \mathrm{m}^{-3}$ and $23.37 \mathrm{ppm}$ $\left(28.897 \mathrm{mg} \mathrm{m}^{-3}\right)$, respectively. The findings revealed that these values reduced to $0.043 \mathrm{mg} \mathrm{m}^{-3}$ and $15.47 \mathrm{ppm}\left(19.129 \mathrm{mg} \mathrm{m}^{-3}\right)$, respectively. An independent sample T-test was used before and after the application of the new system for both crystal silica and formaldehyde concentrations. The findings showed that there was a statistically significant reduction in the quantity of these pollutants $(P<0.001$, Table 3).

Pollutant concentrations were compared with threshold limit values (TLV) established by the NIOSH. The results in Figures 6 and 7 show that the new ventilation system is capable of controlling a major portion of crystal silica pollutants; however, it is deficient in controlling formaldehyde since it was unable to reduce the concentration of this pollutant to an acceptable level.

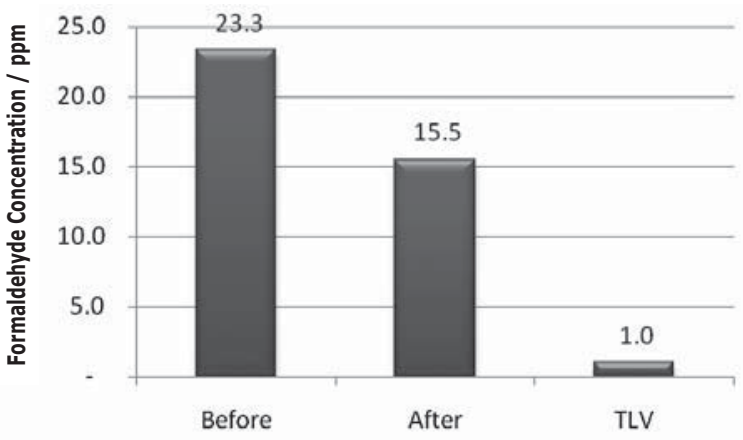

Figure 7 A comparison of mean concentration of formaldehyde measured using individual samplers before and after implementation of the local exhaust ventilation. The threshold limit value (TLV) established by the NIOSH is also shown.

\section{DISCUSSION AND CONCLUSIONS}

Crystalline silica is used in many industries, including foundry. Silica dust is a life-threatening hazard for the respiratory tract. Workers exposed to this pollutant are at risk of developing silicosis (10). A study by Amandus et al. (11) showed that workers exposed to high concentrations of crystalline silica dust suffered from pulmonary complications 1.5 times more than coal miners and 2.4 times more than miners working in mines without any silica. The results brought about by supervision and legal measures from the Occupational Safety and Health Administration (OSHA) in order to adjust working conditions to threshold limits values through engineering controls have proved helpful (10). They are consistent with the objectives of our study. Another study (12) investigated the effectiveness of a local exhaust ventilation system in the foundry industry. The results showed a $59 \%$ to $79 \%$ decrease in silica dust.

Formaldehyde is an organic compound used in core-making and casting (13). Recently, it has been identified as a human carcinogenic factor leading to nasopharyngeal carcinoma and leukaemia $(1,14)$. Based on the findings of the present study and due to the inefficiency of the new system in controlling formaldehyde levels, the use of local exhaust ventilation could not completely eliminate the concentration of pollutants in the working environment. As formaldehyde is produced via many sources and

Table 3 Comparison of crystalline silica and formaldehyde concentrations before and after utilization of ventilation system.

\begin{tabular}{|c|c|c|c|c|c|c|c|c|c|}
\hline \multirow{2}{*}{ Pollutant } & \multicolumn{3}{|c|}{ Before control } & \multicolumn{3}{|c|}{ After control } & \multirow{2}{*}{ MD } & \multirow[t]{2}{*}{$t$} & \multirow{2}{*}{$\boldsymbol{P}^{*}$} \\
\hline & $n$ & Mean & SD & $N$ & Mean & SD & & & \\
\hline Crystalline silica $/ \mathrm{mg} \mathrm{m}^{-3}$ & 40 & 0.2183 & 0.167 & 18 & 0.043 & 0.012 & 0.175 & 6.60 & $<0.001$ \\
\hline Formaldehyde / ppm & 39 & 23.3 & 9.93 & 15 & 15.47 & 4.75 & 7.9 & 3.93 & $<0.001$ \\
\hline
\end{tabular}


is created at different sites within the work environment, multiple systems are necessary to reduce its concentration. Since the application of such a system was not cost-effective, its implementation was not possible. That is why it is advisable to use a combination of ventilation systems and personal protective equipment to alleviate the toxic effects of formaldehyde (15).

Another issue to be noted regarding the implementation of the local exhaust ventilation system is the cost-effectiveness of this system compared to other controlling methods. One parameter that can affect the costs of a local exhaust ventilation system is minimum design duct velocity. Minimum design duct velocity is determined on the basis of pollutant type (set by the ACGIH), while its value ranges from $3500 \mathrm{fpm}$ to $4000 \mathrm{fpm}\left(17.78 \mathrm{~m} \mathrm{~s}^{-1}\right.$ to $\left.20.32 \mathrm{~m} \mathrm{~s}^{-1}\right)$ for the system designed in this research project. Despite the fact that increased speed causes a drop in pressure, the speed used while designing this system ranged between $4000 \mathrm{fpm}$ and $6000 \mathrm{fpm}\left(20.32 \mathrm{~m} \mathrm{~s}^{-1}\right.$ to $30.48 \mathrm{~m} \mathrm{~s}^{-1}$ ). Therefore, it can be asserted that the selection of a minimum design duct velocity of 4000 $\mathrm{fpm}$ to $6000 \mathrm{fpm}\left(20.32 \mathrm{~m} \mathrm{~s}^{-1}\right.$ to $\left.30.48 \mathrm{~m} \mathrm{~s}^{-1}\right)$ in the canal causes a $20 \%$ to $30 \%$ decrease in the cost of the implementation of a local exhaust ventilation system, as well as that a decrease in the duct diameter increases air velocity.

According to the results shown in Table 1, hood 2-A is located in a non-encapsulated environment. While measuring the capture velocity, the vane anemometer was exposed to environmental wind, which caused a greater circulation of the blades, as well as the measured capture velocity values to be higher than the designed ones. Similarly, due to an error in the measuring device, as well as due to the fact that the front of the hood was blocked by a body at the time of measurement because of the large area of the mouth of hood, average capture velocity in hood 7-F was smaller than the designed one.

According to the results shown in Table 2, for channels 1-A and 2-A, the measured value of minimum design duct velocity was significantly closer to the designed value, while this result proved to be inverse for channels H-I and 6-E. This is due to the presence of moisture caused by the evaporation of water and the resin material in the casting mold. The vapours can block the pores of the pitot tube, causing an erroneous indication of the measured velocity pressure values.
In our study, the ventilation system was designed and fabricated by another researcher from a factory in the Islamic Republic of Iran. It was assessed and certain parameters such as flow rate were measured. The measured value was $60 \%$ to $70 \%$ of the designed value. The findings of their study showed that there were discrepancies between the features of the ordered ventilator and those of the fabricated one (16). Yet, this parameter was taken into consideration in the system designed in our study. In fact, it was estimated to be $8 \%$ to $15 \%$ higher than the designed value. The designing and construction of the fan with the desired features was conducted on the basis of exact plans.

It should be mentioned here that some of the desired parameters in the design of the ventilator, such as Equivalent Fan Total Pressure (EFTP) and flow rate, approach their real values, i.e. the designed values, after three to five years. Fan design parameters will reduce by less than $8 \%$ to $15 \%$ of the actual value after 10 to 15 years. This is due to the wear and tear of the parts of the ventilator electromotor and other parts such as blades, back plate, rim, and ball bearing. Wear to fans occurs due to vibration and dust that enters into the electromotor. The blade wears due to the contact between the blade and the pollutants. The deposition of the pollutants on the blades causes the blades to become heavy and reduces the distance between the blades, which in turn reduces the flow rate. Erosion of the back plate and rim increases the distance between these two elements, which causes an internal drop in fan pressure.

\section{CONCLUSION}

This ventilation system was designed according to industrial ventilation standard values and showed that the installed system functions as it was designed. The ventilation system proved to be cost-effective.

\section{REFERENCES}

1. Ahn YS, Won JU, Park RM. Cancer morbidity of foundry workers in Korea. J Korean Med Sci 2010;25:1733-41.

2. Greenberg MI, Waksman J, Curtis J. Silicosis: a review. Dis Mon 2007;53:394-416.

3. Lin MH, Liou SH, Chang CW, Huang IH, Strickland PT, Lai $\mathrm{CH}$. An engineering intervention resulting in improvement in lung function and change in urinary 8- 
hydroxydeoxyguanosine among foundry workers in Taiwan. Int Arch Occup Environ Health 2011;84:175-83.

4. National Occupational Health and Safety Commission. Foundry Health Hazards 1989 [displayed 7 January 2013] Available at http://www.safeworkaustralia.gov.au/sites/SWA/ about/Publications/Documents/32/FoundryHealthHazards 1989 PDF.pdf

5. Howard DG, Esko T. Industrial Ventilation Design Guidebook. San Diego (CA): Academic Press; 2001.

6. Occupational Safety and Health Administration (OSHA). Sampling and Analytical Methods, Method no: 12. Benzene. 1979. Evaluated method. This method has been subjected to the established evaluation procedures of the Organic Methods Evaluation Branch 1980 [displayed 7 January 2013]. Available at http://www.osha.gov/dts/sltc/methods/organic/ org012/org012.html

7. American Conference of Governmental Industrial Hygienists (ACGIH). Industrial Ventilation a Manual of Recommended Practice. 22nd ed. Cincinnati (OH): ACGIH; 1995.

8. NIOSH Manual of Analytical Methods (NMAM). Silica Crystalline by Vis: Method 7601, 2003 [displayed 7 January 2013]. Available at http://www.cdc.gov/niosh/docs/2003154/pdfs/7601.pdf

9. NIOSH Manual of Analytical Methods. Formaldehyde: Method 2541, 1994 [displayed 7 January 2013]. Available at http://www.cdc.gov/niosh/docs/2003-154/pdfs/2541.pdf
10. Yassin A, Yebesi F, Tingle R. Occupational exposure to crystalline silica dust in the United States, 1988-2003. Environ Health Perspect 2005;113:255-60.

11. Amandus HE, Shy C, Wing S, Blair A, Heineman EF. Silicosis and lung cancer in North Carolina dusty trades workers. Am J Ind Med 1991;20:57-70.

12. Gressel MG. An evaluation of a local exhaust ventilation control system for a foundry casting-cleaning operation. Am Ind Hyg Assoc J 1997;58:354-8.

13. Westberg H, Löfstedt H, Seldén A, Lilja BG, Nayström P. Exposure to low molecular weight isocyanates and formaldehyde in foundries using hot box core binders. Ann Occupat Hyg 2005;49:719-25.

14. Zhang L, Steinmaus C, Eastmond DA, Xin XK, Smith MT. Formaldehyde exposure and leukemia: a new meta-analysis and potential mechanisms. Mutat Res 2009;681:150-68.

15. Pei CAO, Wu-dong BA, Yong-bing W. Research on air analysis and air purification device in the foundry workshops. Research Studies on Foundry Equipment 2008;3:25-8.

16. Jafari MJ, Karimi A, Azari MR. The role of exhaust ventilation systems in reducing occupational exposure to organic solvents in a paint manufacturing factory. Indian J Occup Environ Med 2008;12:82. 


\section{Sažetak}

\section{DIZAJN I IZRADA SUSTAVA ZA LOKALNU ISPUŠNU VENTILACIJU I PROCJENA NJEGOVE UČINKOVITOSTI OTKLANJANJA SILIKATNE PRAŠINE I MIKROKRISTALNIH ČESTICA TE FORMALDEHIDA U LJEVAONICI}

Svrha ove studije bila je dizajnirati sustav lokalne ispušne ventilacije i procijeniti njegovu učinkovitost otklanjanja inhalabilne silikatne prašine i mikrokristalnih čestica te štetnih plinova i para u radnoj okolini kojima su izloženi radnici u jednoj ljevaonici. Sustav je dizajniran na temelju preporuka Američke konferencije za higijenu rada (American Conference of Governmental Industrial Hygiene). Nakon osmišljavanja sustava lokalne ispušne ventilacije, pripremili smo plan za njegovu implementaciju te ga predali proizvođaču. Kao pokazatelji učinkovitosti ovoga sustava u kontroli inhalabilne prašine i čestica te drugih zagađivala zraka poslužila su nam mjerenja koncentracije silikatne prašine i formaldehida, koji su uobičajena toksična zagađivala zraka u ljevaonicama. Stupanj profesionalne izloženosti silikatnoj prašini i formaldehidu procijenjen je u dva slučaja: (1) kada je lokalni ventilacijski sustav bio uključen i (2) kada je sustav ventilacije bio isključen. Uzorci zraka koji su radnici udisali u radnom prostoru prikupljeni su pomoću osobnih sakupljača te ispitani metodama propisanim dokumentima Nacionalnog instituta za sigurnost i zdravlje na radu (National Institute for Occupational Safety and Health, krat. NIOSH) br. 7601 za silikatnu prašinu i br. 2541 za formaldehid. Koncentracije silikatne prašine i formaldehida određene su vidljivom apsorpcijskom spektrofotometrijom i plinskom kromatografijom. Rezultati istraživanja pokazali su da je lokalna ispušna ventilacija uspješno otklonila kristalne silikatne čestice te je izmjerena koncentracija u radnom okruženju bila niža od najviše dopuštene koncentracije $\left(0,05 \mathrm{mg} \mathrm{m}^{-3}\right)$, dok je izmjerena koncentracija formaldehida u radnom okruženju bila viša od dopuštene koncentracije propisane od NIOSH-a $\left(1 \mathrm{ppm}=1.228 \mathrm{mg} \mathrm{m}^{-3}\right)$.

KLJUČNE RIJEČI: inhabilna prašina i čestice, profesionalna izloženost, ventilacijski sustav

\section{CORRESPONDING AUTHOR:}

\section{Hossein Kakooi}

School of Health, Tehran University of Medical Sciences

Tehran, Iran

e-mail:fallah_hossein@yahoo.com 